Bull. Fac. Agric, Cairo Univ., 69:15-26 (2018).

\title{
AN ECONOMIC STUDY OF THE TECHNOLOGICAL METHODES USED FOR GRAPE PRODUCTION IN THE NEW LANDS
}

(Received: 27. 1. 2018)

\author{
By \\ M. A. A. Abo El Naga and Z. E. Z. Nassar \\ Department of Economic Studies, Division of Economic and Social Studies, Desert Research Center
}

\begin{abstract}
The main objective of the current research was to study, analyze and evaluate the technological methods used in the production of grapes in the Nubaria region, representing the new lands. This was accomplished by achieving a number of sub-objectives including: (1) To identify the current status of the grape production (area, production, productivity) in both the Republic and the Nubaria area in terms of its importance and development during the period (2000-2015), (2) Identify the relative importance of the area, productivity and production of grapes in the most important grape producing governorates in Egypt for the period (2010-2015), and (3) To identify the impact of the technological methods used in the production of grapes in the study sample on the productivity of the feddan, net yield, and the efficiency of the use of water resources and land as one of the most important determinants of agricultural development in Egypt, The research methods used were both the descriptive and quantitative of data to achieve its objectives. Statistical analysis of the research was based on secondary data, published and unpublished, by the relevant government agencies. In addition to the preliminary data obtained from the field study carried out in the Nubaria area for the grape season 2015/2016, which was collected using the questionnaire forms prepared for this purpose in personal interviews with farmers.

The research reached a number of results, the most important of which are:

1- An annual increase (statistically significant) in each of the productive area (3 thousand feddans), productivity $(0,21$ tons/feddan) and total production (48,2 thousand tons) for the grape harvest at the level of the Republic during the study period.

2 - An annual increase (statistical significance) in both fruit area (2,9 thousand feddans), productivity ( 0.20 ton/feddan) and total production (45.4 thousand tons) for the grape harvest at the level of the republic during the study period.

3 - The new land (Nubaria) comes in the first place in terms of fruitful area of grapes, contributing alone about $52.3 \%$ of the total fruit area of grapes in Egypt, and in terms of productivity of $110.7 \%$ of the average productivity of grapes in the Republic, In terms of the total production, Nubaria produces about $58.4 \%$ of the total production of grapes in the Republic as an average for the period 2010-2015.

4 - The pattern of agricultural development of the grape harvest is a vertical development, since the productivity of the crop yields more than the productive area despite the sensitivity of this crop to the weather conditions. .

5 - With regard to the productivity of the Fidelity King Roby superior morale on the two varieties Superior and Thompson by about $20.92 \%, 29.85 \%$, respectively. The yield of grape fruit cultivated in the form of yield was significantly higher than that of the Y-shape and Y-shape by $8.33 \%$ and $19.17 \%$, respectively.

6- With regard to the net yield of Fedan, the class Flim significantly superior to Thomson by about $37.71 \%$, followed by Superior in second place, while Thomson comes in the last place, where the superiority of the two varieties Superior and Philem superiority. The net yield of cultured grapes was significantly higher than that of Y-shape.

7 - With regard to the efficiency of irrigation water use, Thomson is superior to Flim and King Robbie, and Flim is in the last position, with both Thomson and Superior superior. Grape cultivars were significantly higher than $\mathrm{Yb}$ (Y-shape).
\end{abstract}


(2) التعرف على الأهمية النسبية لمسـاحة و إنتاجية و إنتاج

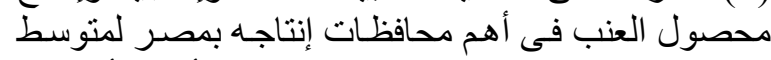
الفترة (2010-2015). (3) التعـرف على أنى أنـر الأسـاليب

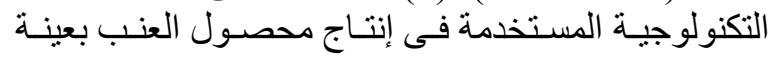

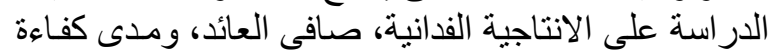

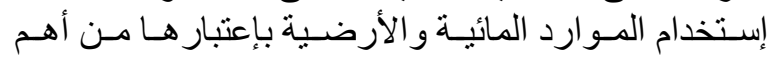
محدات التنمية الزر اعية في مصر.

\section{4. الطريقة البحثية ومصادر البيانات}

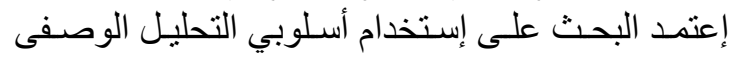

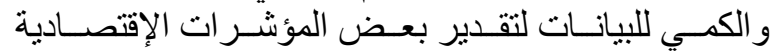

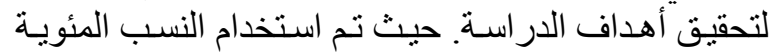

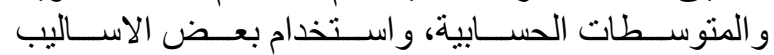

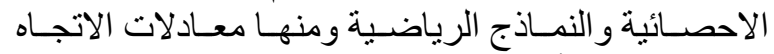

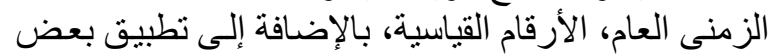

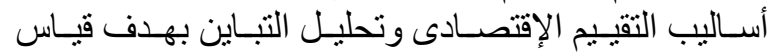

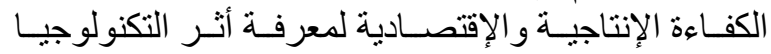

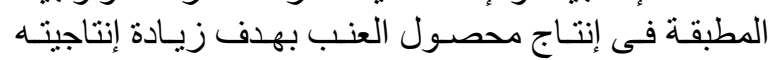

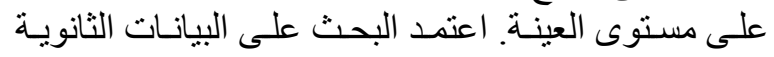

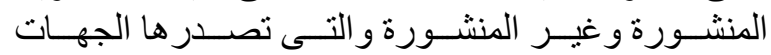

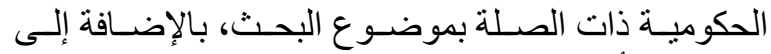

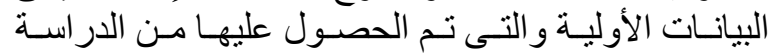

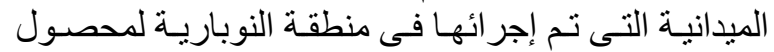

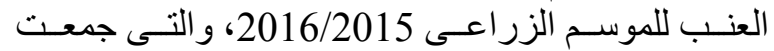

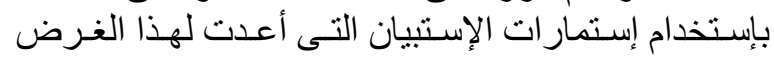
وذللك بالمقابلات الثخصية مع الزراع. الإن.

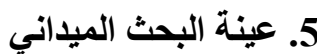

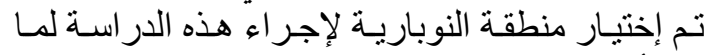

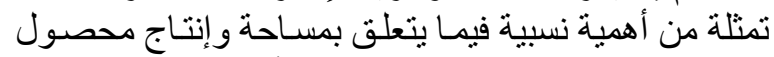

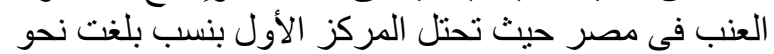

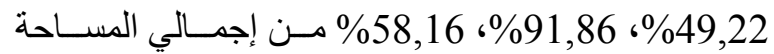

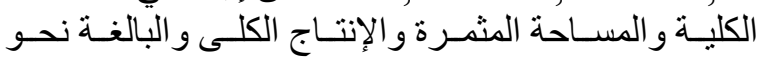

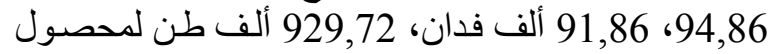

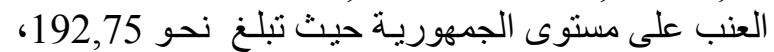

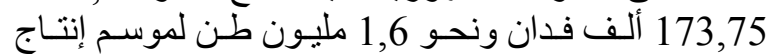

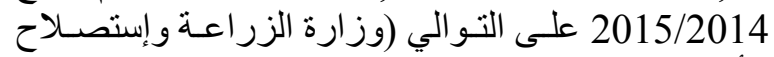

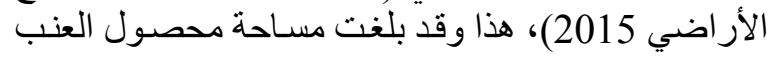

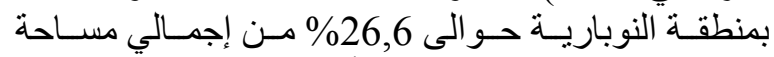

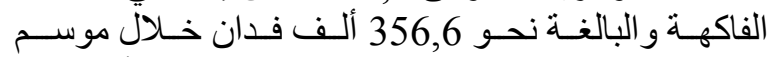

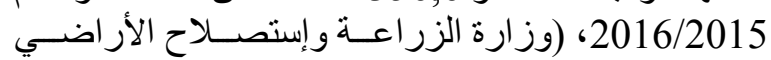

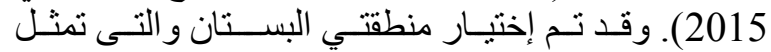

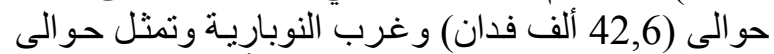

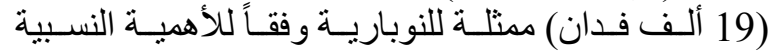

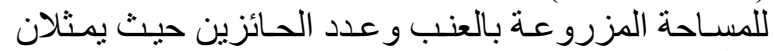

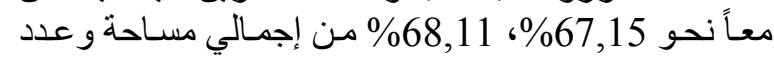

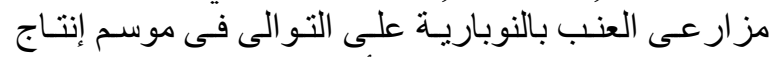

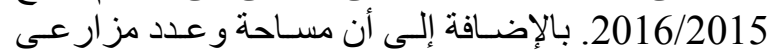

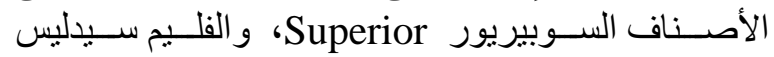
Thompson Flame seedless

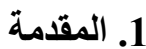

يعتبر محصول العنب من أهم محاصيل الفاكهة فى العى

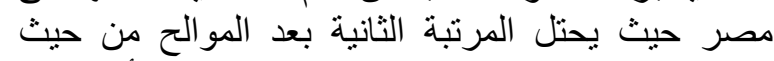
المساحة الكلية المنزر عة به والتى تبلغ نحو 193 ألف فئ فدان تمثل حوالي 11,7\% من إجمالي مساحة الفاكهة على على الفئ مستوى الجمهورية والتى تقدر بنحو 1652 ألف فدان فى الفى

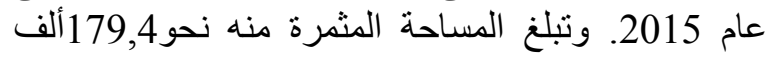
فدان تنتج حوالي 1,71 مليون طن لنفس النعام العام، (وزارة

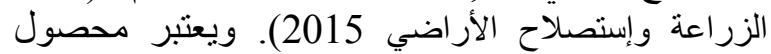

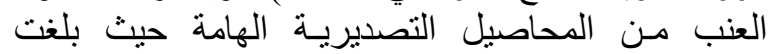

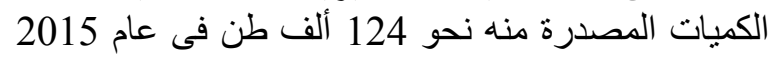

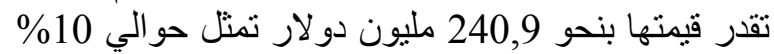

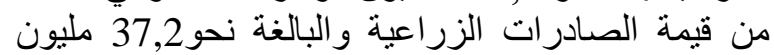
جنيه. (الجهاز المركزي للتعبئة العامة والإحصاء العاء 2015)

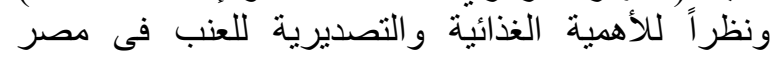

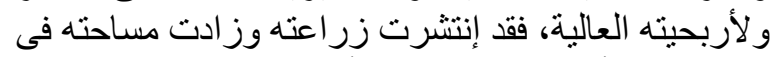

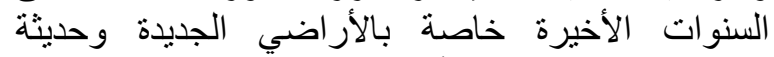

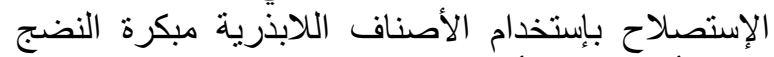
حيث أنها من الأصناف المطلوبة الأناف للتصدير، (الكيلانى

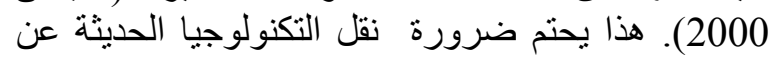

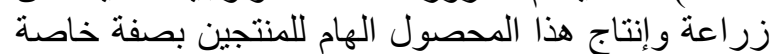

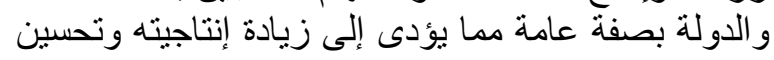
جودنه. (القاضي 2005).

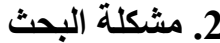

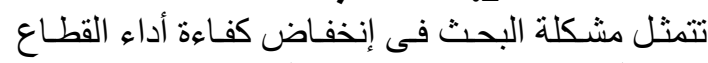

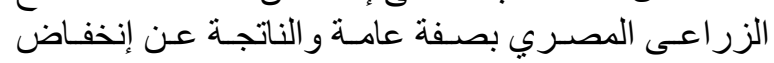

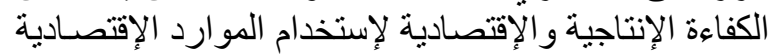

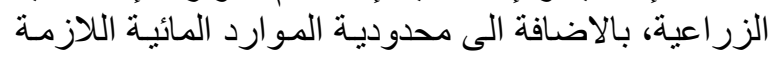

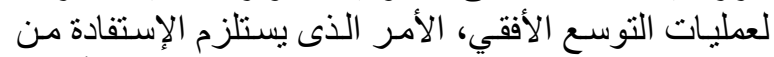

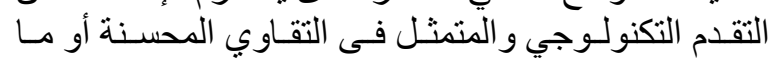

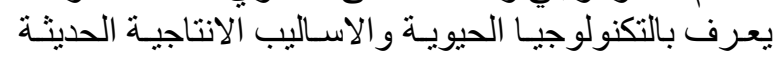

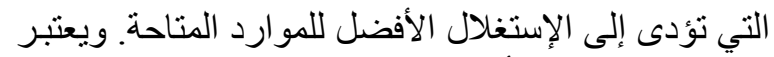

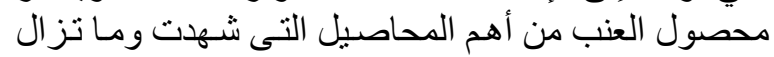

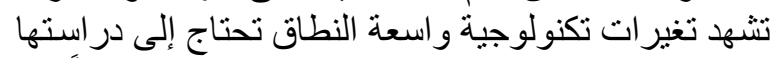

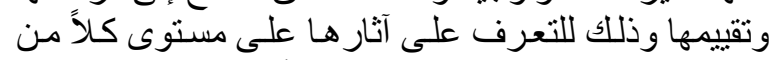

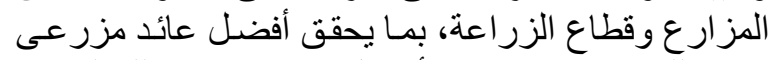

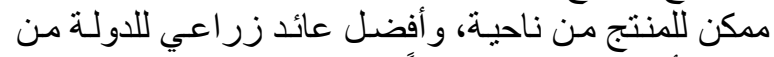

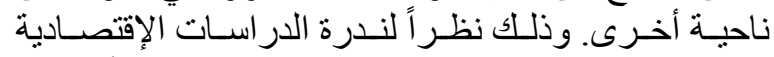

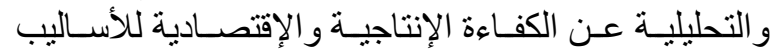
التكنولوجية و الموارد المستخدمة في إنتاج محصول الإنياجة العنب.

\section{3. أهداف البحث}

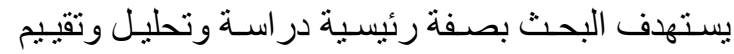

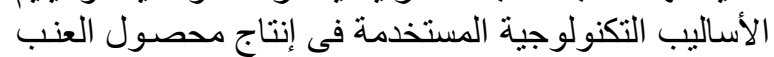

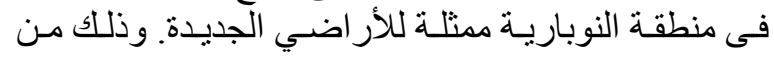

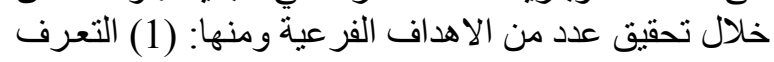

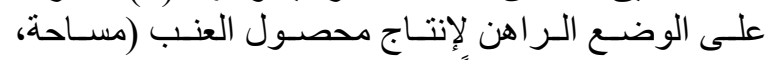

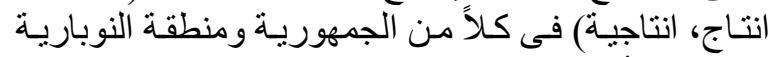
من حيـث أهميتهـه وتطوره خـلادل الفترة (2000-2015). 


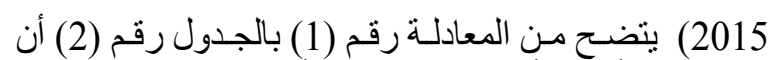

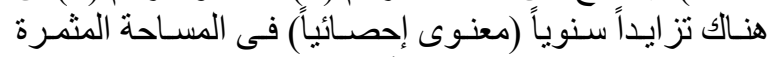

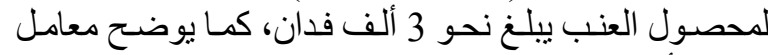

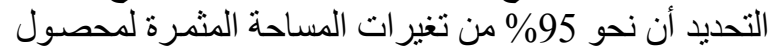

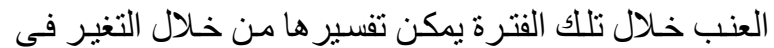
العو امل المختلفة المرتبطة بالزمن.

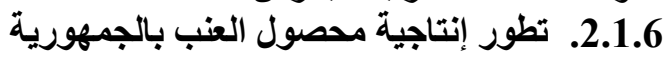

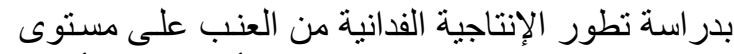

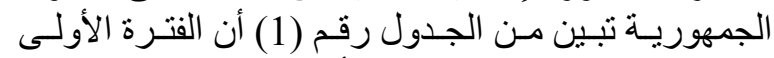

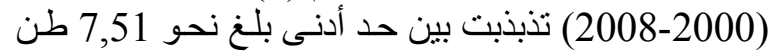

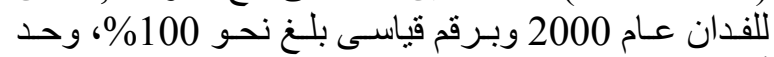

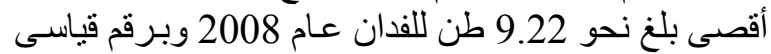

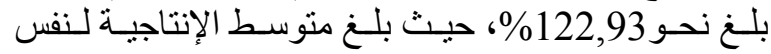

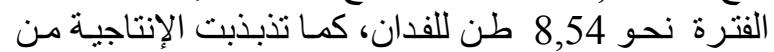
العنب خلال الفترة الثانية (2009-2015) بين حد أدنى بلغ لفن

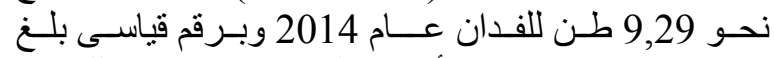

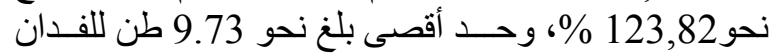

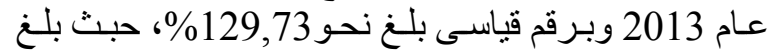

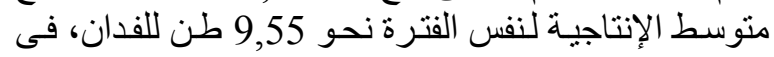

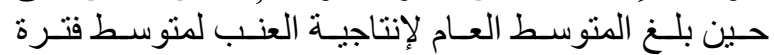

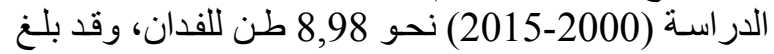

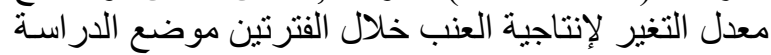

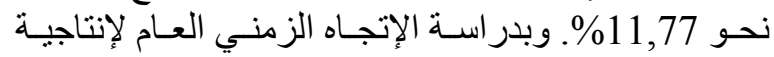

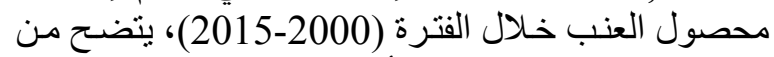

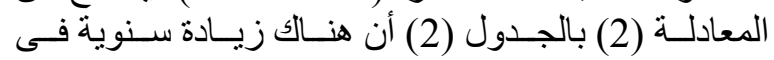
الإنتاجية تبلغ نحو 0,21 طن للفذان، ويشير معامل التحديد

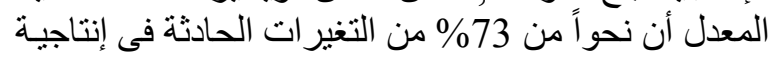

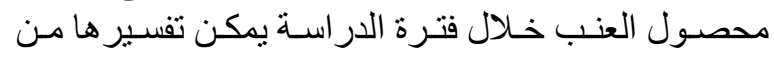

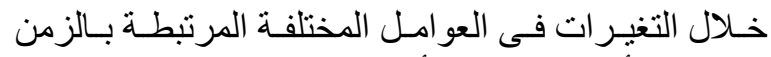

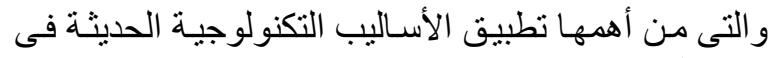
إنتاج العنب. - مئ.

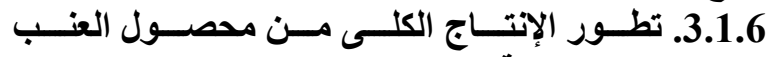 بالجمهورية}

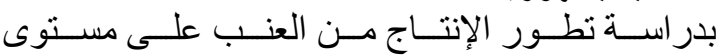

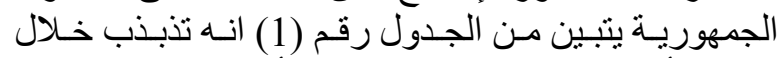

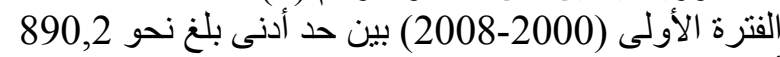

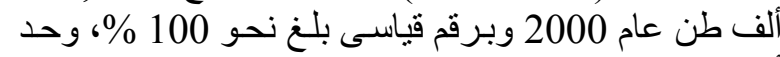

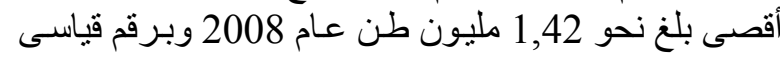

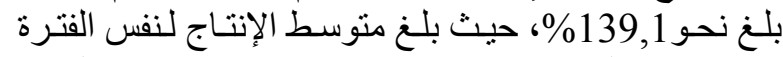

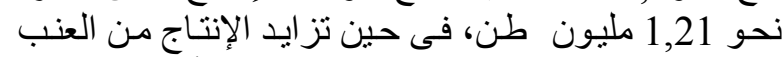

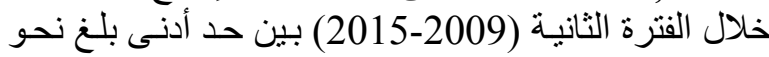

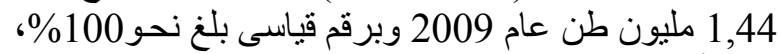

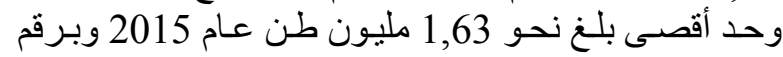

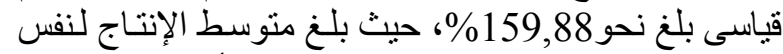

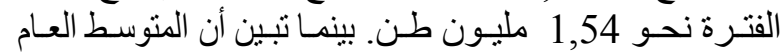

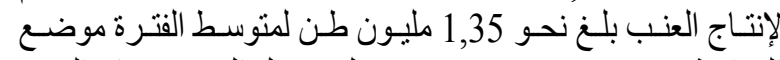

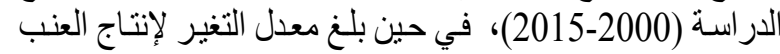

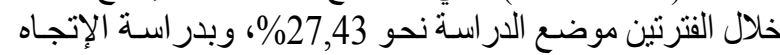

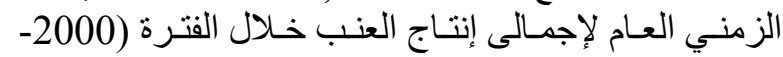

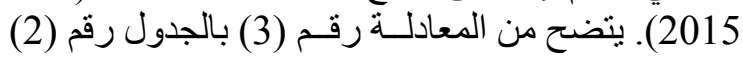

King Ruby seedless seedless

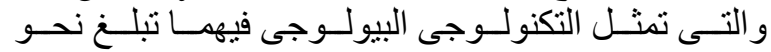

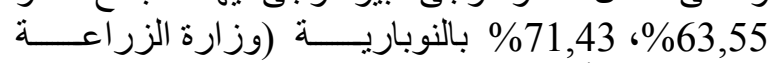

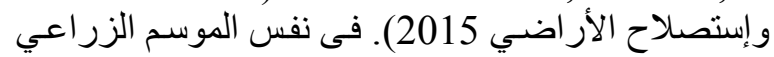

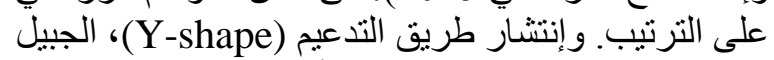

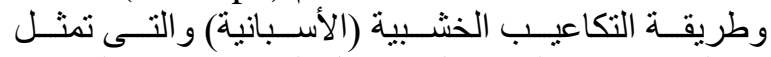

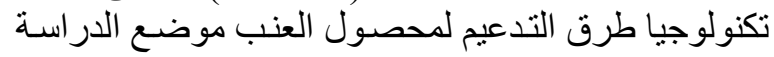

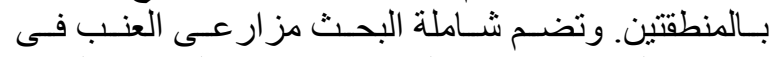

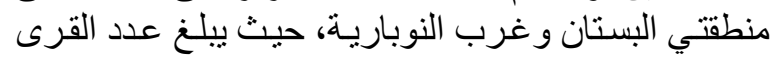

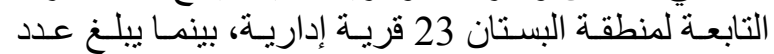

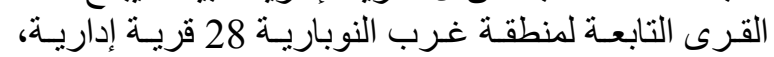

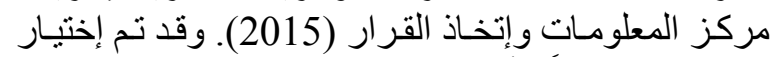

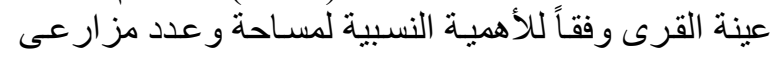

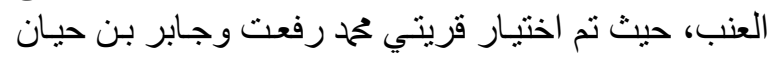

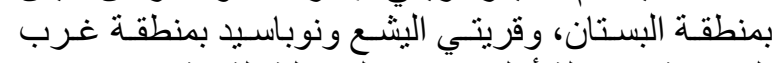

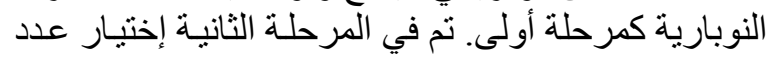

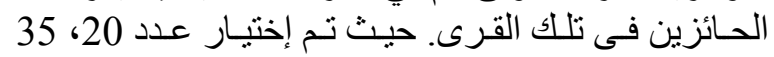

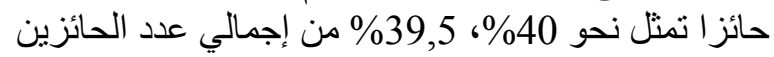

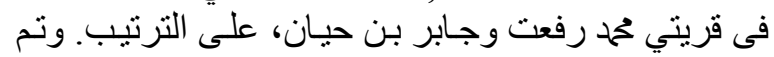

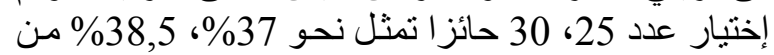

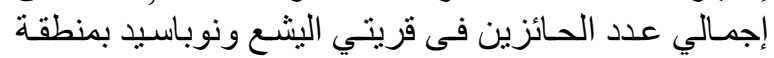
غرب ألنوبارية على التو الي.

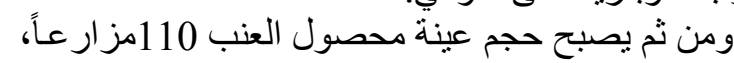

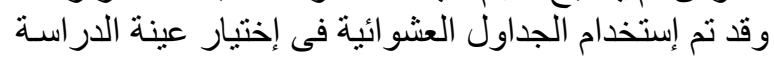

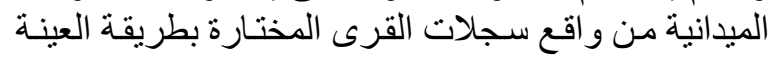
العشو ائية المنتظمة. (سرحان 1980)

\section{6. النتائج البحثية والمناقشة

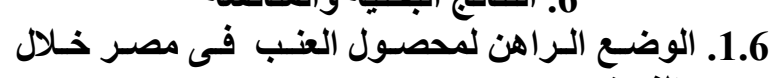 الفترة (2015-2000) \\ 1.1.6. تطـور المســاحة المثــرة للعنـب علـى مسـتوى الجمهورية}

تشير بيانـات الجدول رقم (1) إلى تطور المسـاحة المثمرة

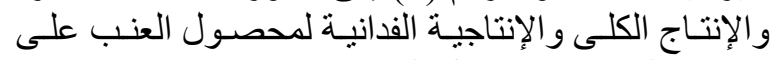

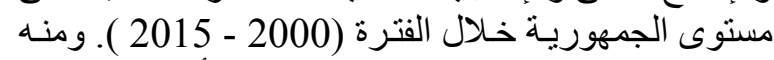

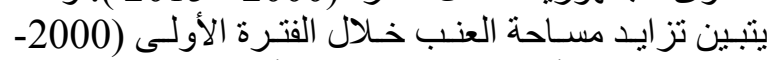

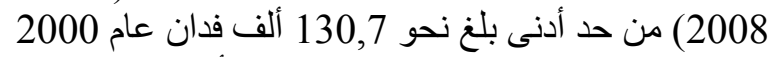

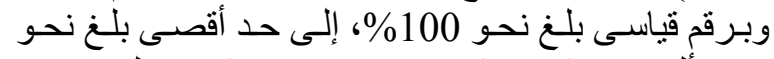

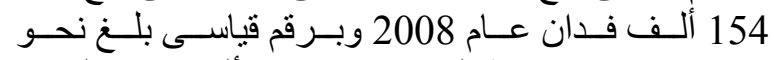

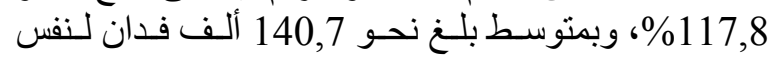
الفترة. كما تزايدت المساحة المثمرة من العنب خلال الفترة

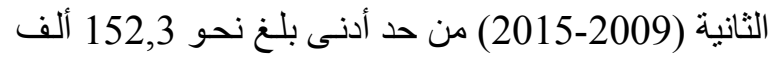

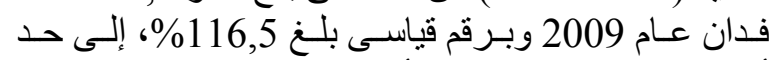

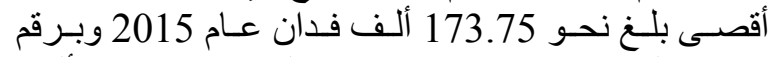

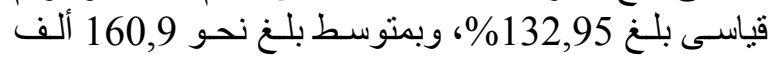

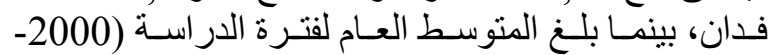

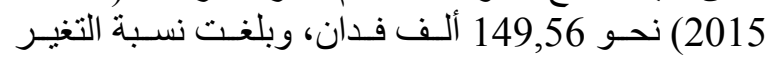

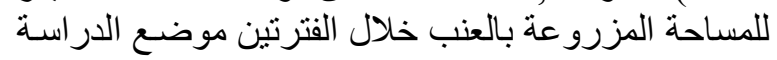

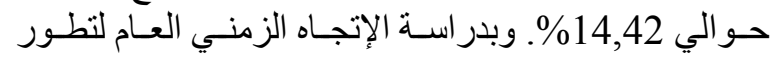

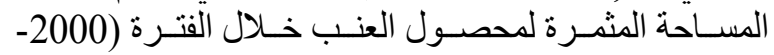


جدول رقم (1): المساحة المثمرة وإنتاج وإنتاجية محصول العنب على مستوى جمهورية مصر خلال الفترة 2000 - 2015.

\begin{tabular}{|c|c|c|c|c|c|c|}
\hline \multicolumn{2}{|c|}{ إنتاجية } & \multicolumn{2}{|c|}{ الإنتاج } & \multicolumn{2}{|c|}{ المساحة المثمرة } & \multirow[b]{2}{*}{ السنوات } \\
\hline القرقم & طن/فدان & القياسمى & ألف طن & القياسمى & ألف فدان & \\
\hline 100.00 & 7.5 & 96.0559 & 980,205 & 100.00 & 130,694 & 2000 \\
\hline 110.13 & 8.26 & 106.60 & 1087,792 & 100.77 & 131,694 & 2001 \\
\hline 106.93 & 8.02 & 105.22 & 1073,710 & 102.44 & 133,879 & 2002 \\
\hline 117.20 & 8.79 & 117.29 & 1196,934 & 104.19 & 136,170 & 2003 \\
\hline 109.47 & 8.21 & 111.43 & 1137,077 & 105.97 & 138,499 & 2004 \\
\hline 114.93 & 8.62 & 122.17 & 1246,659 & 110.66 & 144,624 & 2005 \\
\hline 121.60 & 9.12 & 131.62 & 1343,102 & 112.68 & 147,270 & 2006 \\
\hline 121.87 & 9.14 & 133.78 & 1365,141 & 114.28 & 149,359 & 2007 \\
\hline 122.93 & 9.22 & 139.10 & 1419,474 & 117.80 & 153,956 & 2008 \\
\hline 126.40 & 9.48 & 141.47 & 1443,633 & 116.52 & 152,282 & 2009 \\
\hline 128.67 & 9.65 & 144.18 & 1471,239 & 116.65 & 152,460 & 2010 \\
\hline 127.47 & 9.56 & 144.62 & 1475,768 & 118.11 & 154,369 & 2011 \\
\hline 129.87 & 9.74 & 150.58 & 1536,641 & 120.71 & 157,766 & 2012 \\
\hline 129.75 & 9.731 & 156.69 & 1598,901 & 125.72 & 164,310 & 2013 \\
\hline 123.82 & 9.29 & 156.42 & 1596,169 & 131.51 & 171,882 & 2014 \\
\hline 125.20 & 9.39 & 159.88 & 1631,531 & 132.95 & 173,752 & 2015 \\
\hline 113.90 & 8.54 & 118.14 & 1205,566 & 107.64 & 140,683 & متوسط الفترة الأولى \\
\hline 127.31 & 9.55 & 150.55 & 1536,269 & 123.17 & 160,974 & متوسط الفترة الثانية \\
\hline 11.78 & 11.78 & 27.43 & 27.43 & 14.42 & 14.42 & معدل التغير \\
\hline 119.76 & 8.98 & 132.32 & 1350,249 & 114.44 & 149,560 & المتوسط العام \\
\hline
\end{tabular}

المصدر: جمعت وحسبت من وزارة الزراعة واستصلاح الأراضي - قطاع الثئون الاقتصادية- نشرة الاقتصاد الزراعي- أعداد مختلفة (2001-2016). 


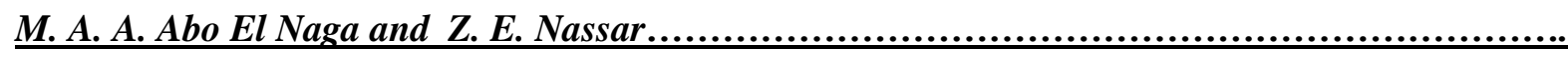

جدول رقم (2): معادلات الاتجاه الزمني العام لتطور كلاً من المساحة المثمرة و إنتاج و إنتاجية محصول العنب على مستوى جمهورية مصر خلال الفترة 2000-2015.

\begin{tabular}{|c|c|c|c|c|c|}
\hline $\mathbf{F}$ & $\mathbf{R}^{2}$ & معادلة الانحدار & & الوحدة & المتغير \\
\hline${ }^{* * *} 182$ & 0,95 & 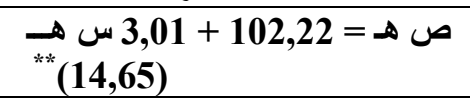 & 1 & بالإلف فدان & المساحة \\
\hline ***53 & 0,75 & $\begin{array}{l}\text { ص هـ = 6,41 + 0,21 س هـ } \\
*(7,13)\end{array}$ & 2 & طن/ فدان & متوسط الإنتاجية \\
\hline ***196,9 & 0,96 & 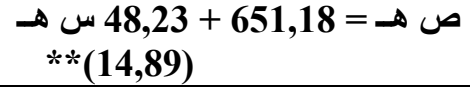 & 3 & بالألف طن & الإنتاج الكلى \\
\hline
\end{tabular}

حيث:

ص^^هـ = المساحة المثمرة التقديرية لمحصول العنب فى مصر بالألف فدان خلال السنة هـ.

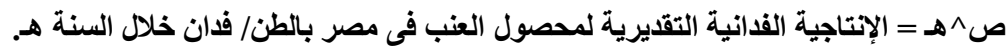

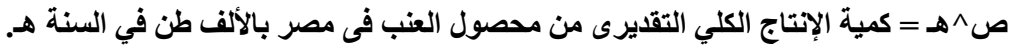

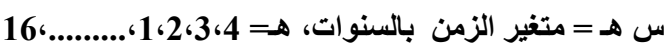

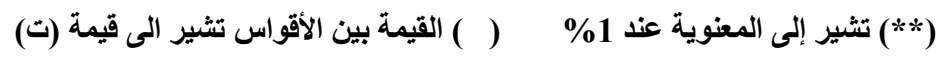
المصدر: جمعت وحسبث من جدول رقم (1).

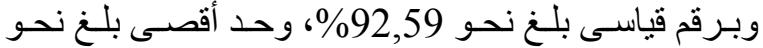

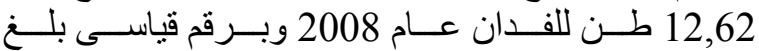

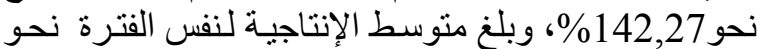

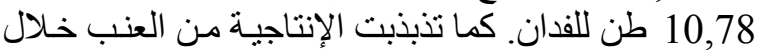

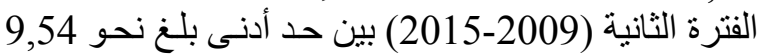

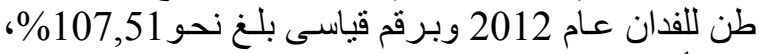

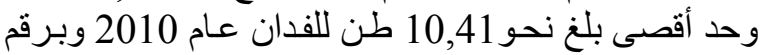

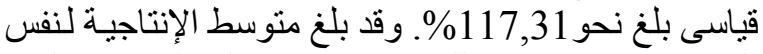

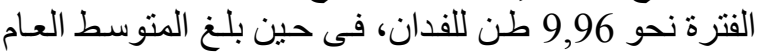

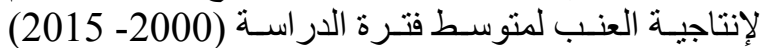

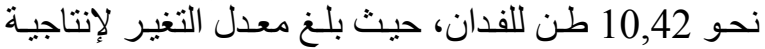

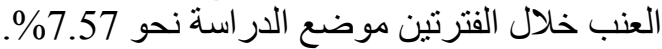

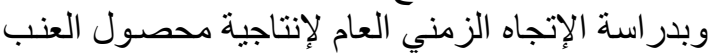

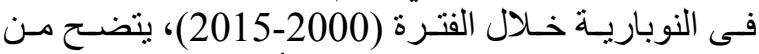

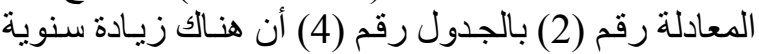

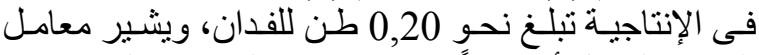

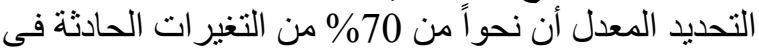

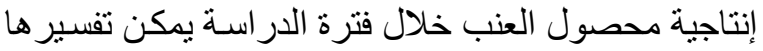

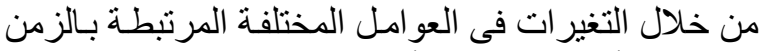
و التى من أهمها تطبيق الأسـاليب التكنولوجيـة الحديثة فى التى

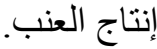

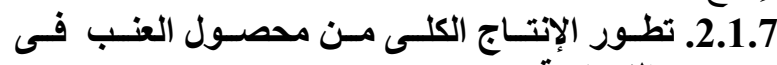
النوبارية الانية

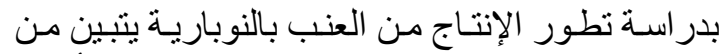

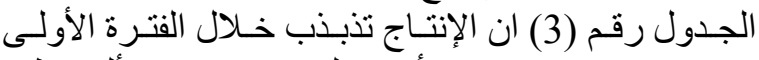

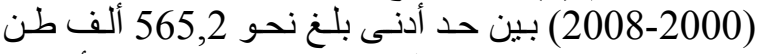

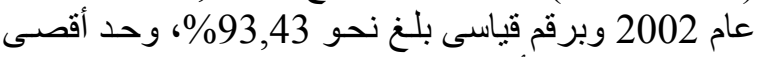

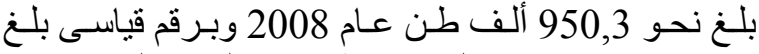
نحو 143,62\%، وقد بلغ منوسط الإنتاج لنفس الفترة نحو

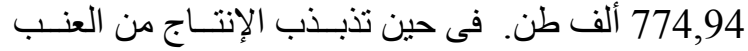

7. الوضـع الـراهن لمحصـول العنب فـ النوباريـة خـلال 7. الفترة (2000- 2015).

1.7. تطور المساحة المثمرة للعنب فى النوبارية

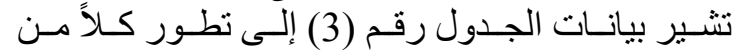

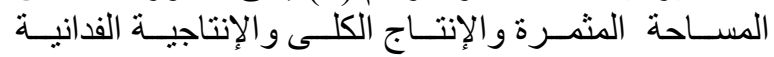

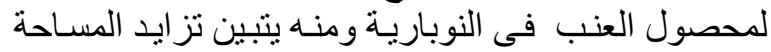

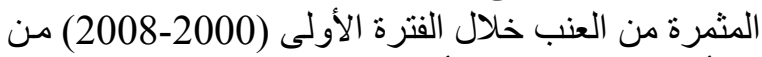

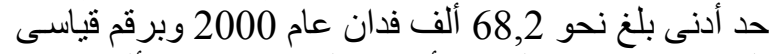

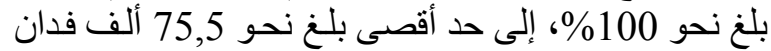
عام 2007 وبرقم قياسى بلغ نحو

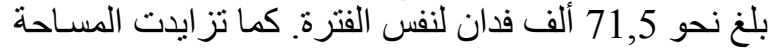

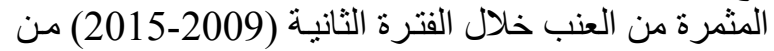

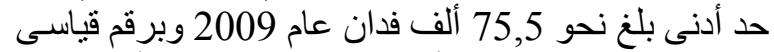

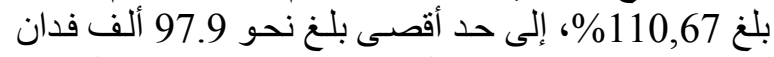

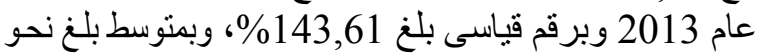

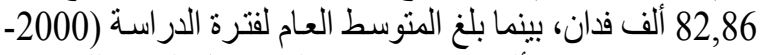

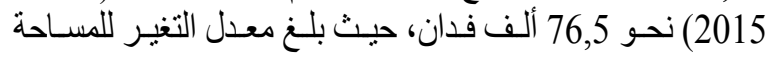

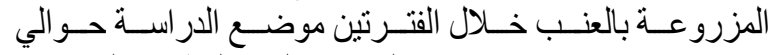

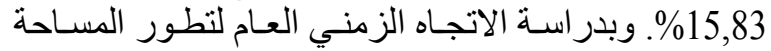

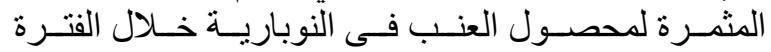

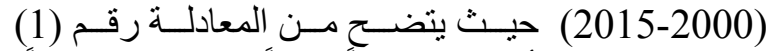
بالجدول رقم (4) أن هناك تز ايداً سنوياً (معنوى إحصائياً)

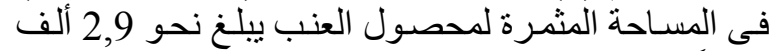

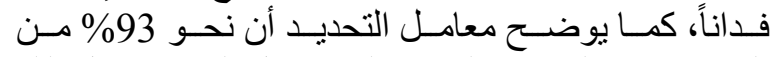

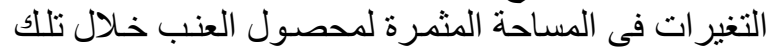
الفترة يمكن تفسير ها من خلال التغير في التئيرة العو امل المختلفة

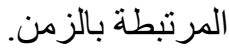

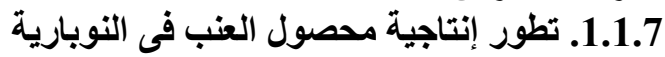

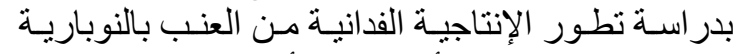
تبين من الجدول رقم (3) أن الفترة الأولى (2000-2008) تذبذبت بين حد أدنى بلغ نحو 8,21 طن للفدان عام 2002 
جدول رقم (3): المساحة المثمرة و إنتاج و إنتاجية محصول العنب فى النوبارية خلال الفترة 2000-2015.

\begin{tabular}{|c|c|c|c|c|c|c|}
\hline \multicolumn{2}{|c|}{ إنتاجية } & \multicolumn{2}{|c|}{ الإنتاج } & \multicolumn{2}{|c|}{ المساحة المثرة } & \multirow{2}{*}{ السنوات } \\
\hline الرقم القياسى & طن/فدان & الرقم القياسى & طن & الرقم القياسى & فدان & \\
\hline 100.00 & 8.87 & 100.00 & 604889 & 100.00 & 68195 & 2000 \\
\hline 104.89 & 9.30 & 105.84 & 640209 & 100.90 & 68812 & 2001 \\
\hline 92.59 & 8.21 & 93.43 & 565158 & 100.90 & 68812 & 2002 \\
\hline 120.38 & 10.68 & 124.17 & 751085 & 103.15 & 70340 & 2003 \\
\hline 123.38 & 10.94 & 128.12 & 775013 & 103.84 & 70817 & 2004 \\
\hline 130.71 & 11.59 & 139.43 & 843411 & 106.67 & 72746 & 2005 \\
\hline 137.95 & 12.24 & 148.28 & 896955 & 107.49 & 73304 & 2006 \\
\hline 141.52 & 12.55 & 156.63 & 947411 & 110.67 & 75473 & 2007 \\
\hline 142.27 & 12.62 & 157.11 & 950326 & 110.43 & 75309 & 2008 \\
\hline 116.75 & 10.36 & 129.21 & 781588 & 110.67 & 75474 & 2009 \\
\hline 117.31 & 10.41 & 131.49 & 795389 & 112.09 & 76437 & 2010 \\
\hline 107.85 & 9.57 & 120.50 & 728875 & 111.73 & 76192 & 2011 \\
\hline 107.51 & 9.54 & 120.40 & 728295 & 111.99 & 76371 & 2012 \\
\hline 108.50 & 9.62 & 126.85 & 767329 & 143.61 & 97933 & 2013 \\
\hline 114.25 & 10.13 & 143.62 & 868727 & 125.71 & 85727 & 2014 \\
\hline 114.10 & 10.12 & 153.70 & 929715 & 134.70 & 91860 & 2015 \\
\hline 121.52 & 10.78 & 128.11 & 774939.67 & 104.90 & 71534.22 & متوسط الفترة الأولى \\
\hline 112.33 & 9.96 & 132.25 & 799988.29 & 121.50 & 82856.29 & متوسط الفترة الثانية \\
\hline 7.57 & 7.57 & 3.23 & 3.23 & 15.83 & 15.83 & معدل التغير \\
\hline 117.50 & 10.42 & 129.92 & 785898.44 & 112.16 & 76487.63 & المتوسط العام \\
\hline
\end{tabular}

جدول رقم (4): معادلات الإتجاه الزمني العام لتطور كلاً من المساحة المثمرة و إنتاج وإنتاجية محصول العنب فى النوبارية خلال

\begin{tabular}{|c|c|c|c|c|c|}
\hline & & & & \multicolumn{2}{|c|}{ الفترة (2000- 2015). } \\
\hline $\mathbf{F}$ & $\mathbf{R}^{2}$ & \multicolumn{2}{|l|}{ معادلة الانحدار } & الوحدة & المتغير \\
\hline "** 142 & 0,93 & ص هـ = 2,91 + 98,51 س هـ & 1 & بالإلف فدان & المساحة \\
\hline ***33 & 0,70 & ص هـ = 0. $0.19,6+5,62$ س هـ & 2 & طن/ فدان & متوسط الإنتاجية \\
\hline${ }^{* * *} 175,4$ & 0,94 & ص هـ = 45,43 + 586,74 س هـ & 3 & بالألف طن & الإنتاج الكلى \\
\hline
\end{tabular}

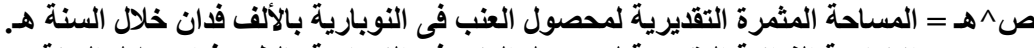

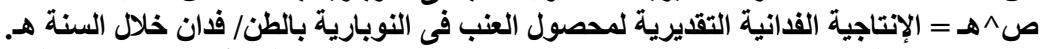

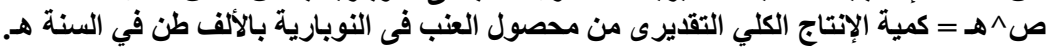

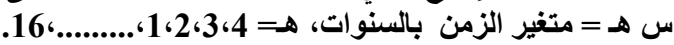

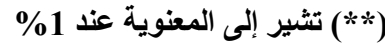

لمتوسط الفترة موضـع الدراسـة (2000-2015)، في حين

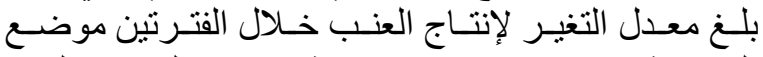

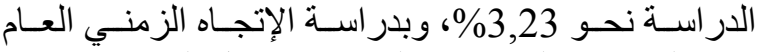

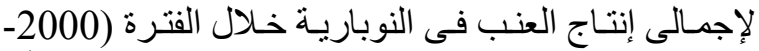

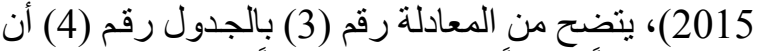

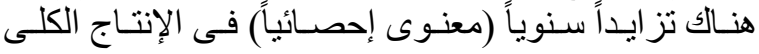

خلال الفترة الثانية (2009-2015) بين حد أدنى بلغ نحو

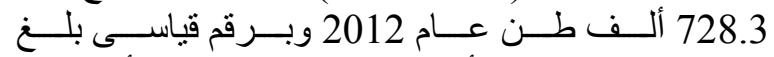

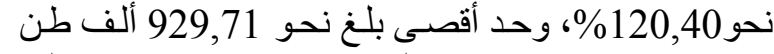

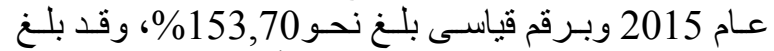

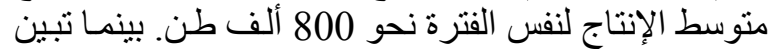
أن المتوسط العام لإنتاج العنب قد بلـغ نحو 786 ألف طن لفن 


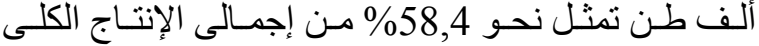

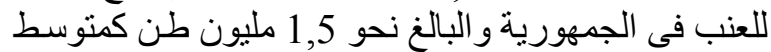

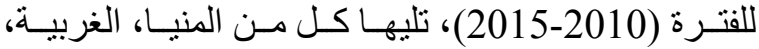

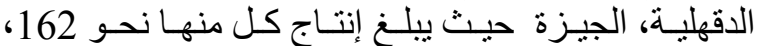

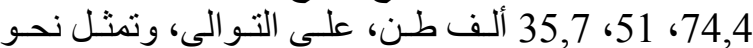

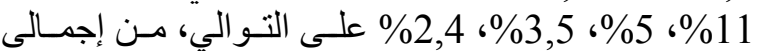

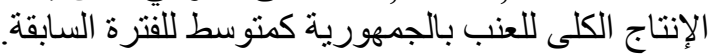

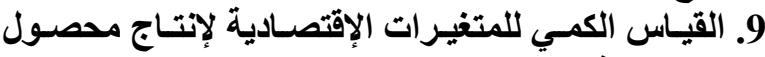

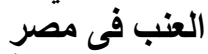

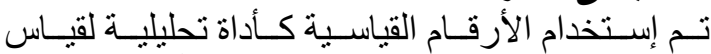

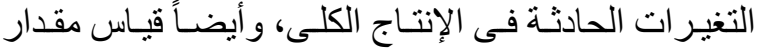

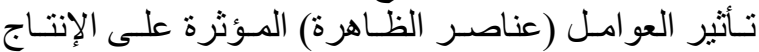

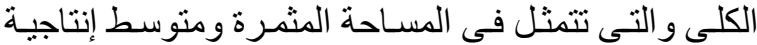

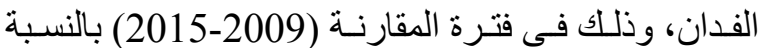

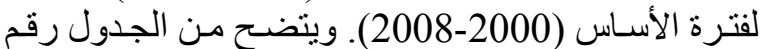
(6) أن الإنتاج الكلى من محصول العنب قد نز ايد في فترة

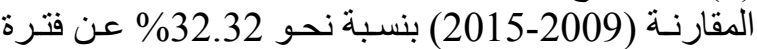

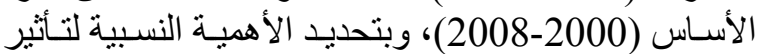
كل من المسـاحة المثـرة والإنتاجيـة الفدانية على الإنتاج
للعنب يبلغ نحو 45,4 ألف طن. كما بشير معامل التحديد

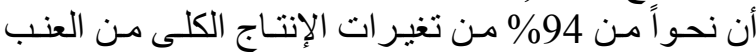

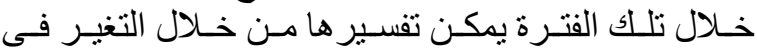
العو امل المختلفة المرتبطة بالزمن الفئ

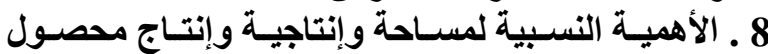
العنب فى أهم محافظات إنتاجه خلال للفترة (2010-

\section{(2015}

1.8

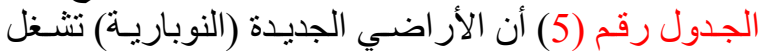

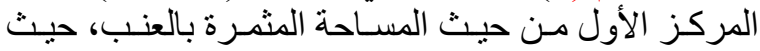

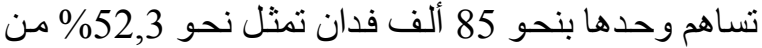

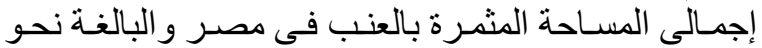

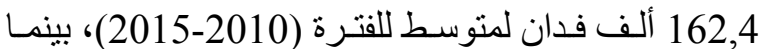

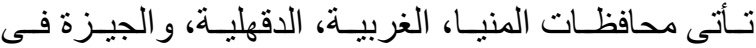

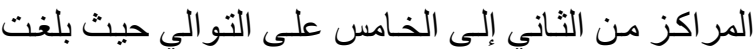

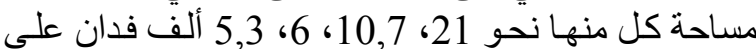

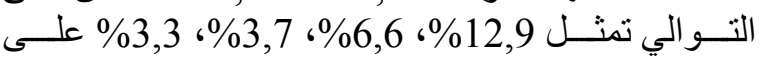

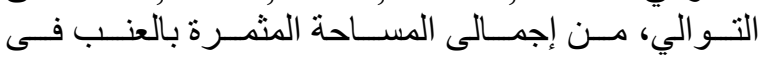
الجمهورية كمتوسط لنفس الفترة.

جدول (5): الأهمية النسبية للمساحة وإلاتتاجيه لمحصول العنب فى أهم محافظات إنتاجه بجمهورية مصر العربية لمتوسط للفترة .(2015-2010)

\begin{tabular}{|c|c|c|c|c|c|c|}
\hline \multicolumn{2}{|c|}{ كمية الإنتاج } & \multicolumn{2}{|c|}{ الإتتاجية } & \multicolumn{2}{|c|}{ المساحة المثمرة } & \multirow{2}{*}{ المحافظات البيان } \\
\hline \% للجمهورية & ألف طن & \% للجمهورية & طن/فدان & \% للجمهورية & ألف فذان & \\
\hline $\mathbf{5 8 . 4 2}$ & 853.21 & 110.69 & 9.90 & 52.30 & 84.95 & النوبارية \\
\hline 11.10 & 162.11 & 85.82 & 7.67 & 12.94 & 21.02 & المنيا \\
\hline 5.09 & 74.39 & 78.36 & 7.01 & 6.61 & 10.74 & الغربية \\
\hline 3.50 & 51.05 & 94.00 & 8.40 & 3.71 & 6.02 & الدقهلية \\
\hline 2.44 & 35.66 & 86.86 & 7.77 & 3.29 & 5.34 & الجيزة \\
\hline 19.45 & 284.15 & 0.00 & 0.00 & 21.15 & 34.35 & باقي المحافظات \\
\hline 100 & 1460.57 & 100 & 8.94 & 100 & 162.42 & إجمالّى الجمهورية \\
\hline
\end{tabular}

المصدار: جمعت وحسبت من وزارة الزراعة واستصلاح الأراضيـ قطاع الثئون الاقتصادية_ نثرة الإحصاءات الزراعيةــــأعداد مختلفة (2011-

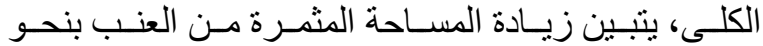

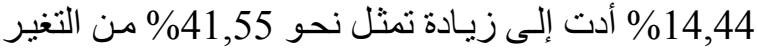

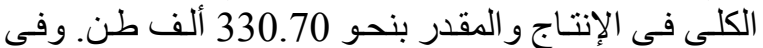

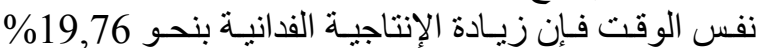

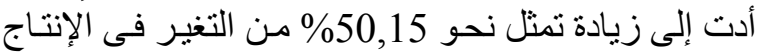
الكلى، وترجع الزيادة المنتقية في الإنتاج الكلى إلى التى التأثير

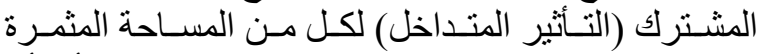

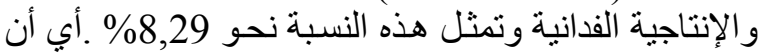

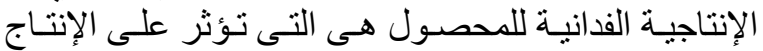

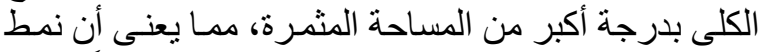

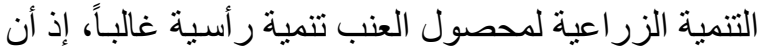

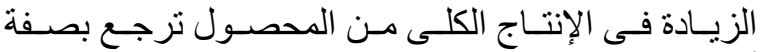
أساسية إلى زيادة إلانتاجية الفدانية على الر غم من حساسية هذا المحصول للظروف الجوية.
1.1.8 الأهمية النسبية للإنتاجية الفدانية

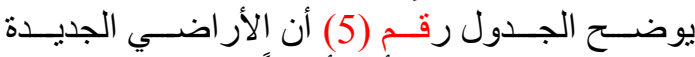

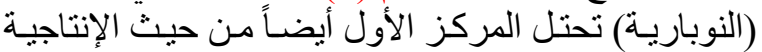
الفدانية حيث تبلغ نحو 9,9 طن للفدان تمثل حو الي الئ 110,7 \% من منوسط إنتاجية العنب فى الجمهورية و البالغ حو الي للئ

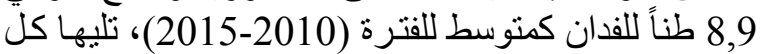

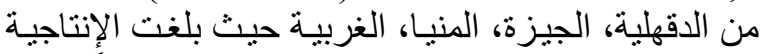

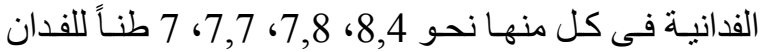

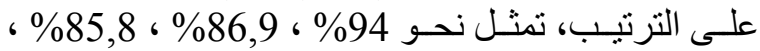

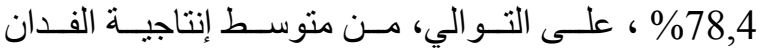
بالجمهورية كمتوسط للفترة السابقة. 2.1.8 الأهمية النسبية للإنتاج الكلى الكية.

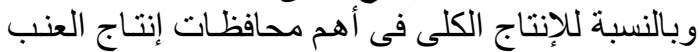
يتبين من الجدول رقم (5) أن الأر اضي الجديدة (النوبارية)

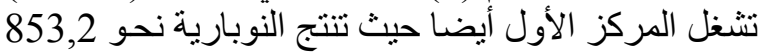


جدول رقم (6) : التغيرات النسبية ونتائج تحليل أثر المساحة المثرة والإنتاجية على التغير فى الإنتاج الكلى لمحصول العب فى مصر

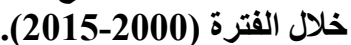

\begin{tabular}{|c|c|c|c|c|c|c|c|}
\hline \multirow[b]{2}{*}{ الألثمية النسبية } & \multicolumn{3}{|c|}{ تأثير تغير عناصر الإنتاج الكلى } & \multicolumn{3}{|c|}{ متوسط فترة الاراسة } & \multirow[b]{2}{*}{ الإنتاج الكلى } \\
\hline & أو متتابعل & أو متشاختى & منفصل & القياسي & فترة المقارنة & فترة الأسساس 2008 -2008 & \\
\hline 49.85 & 164.84 & 27.43 & 137.41 & 114.44 & 160.97 & 140.68 & المساحةٌ المثُمرة \\
\hline 50.15 & 165.86 & - & 165.86 & 119.76 & 9.55 & 8.54 & الإنتاجية \\
\hline 100 & 330.70 & 27.43 & 303.27 & 132.32 & 1536.27 & $\mathbf{1 2 0 5 . 5 7}$ & الإنتاج الكلى \\
\hline- & - & - & - & 27.43 & - & 330.70 & فروق الإتتاج \\
\hline
\end{tabular}

حيث: المساحة المثرة بالألف فدان، الإنتاجية بالطن/فانان، الإنتاج بالألف طن. المصدر: بيانات الجداول رقم (1)، رقم (2) الأفتاجة

وبتطبيق إختبار أقل فرق معنوى L.S.D بعد ترتيب

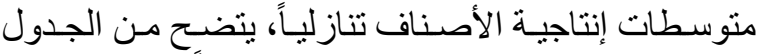

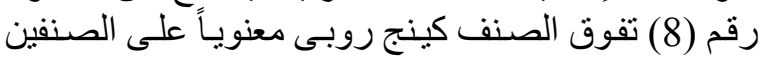

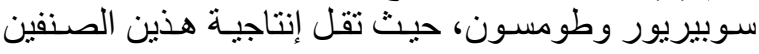

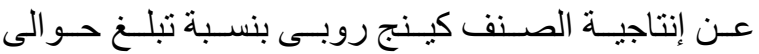

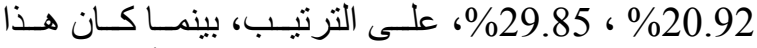

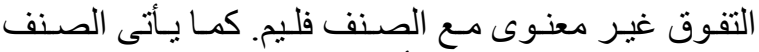

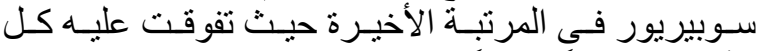
الأصناف تفوقاً معنوياً. كمـا يتضـح من بيانـات الجدول رقيا.

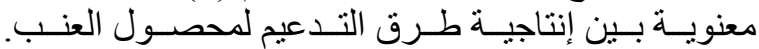

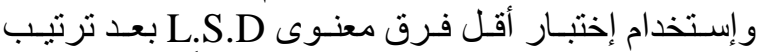

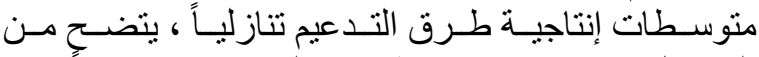

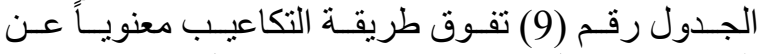

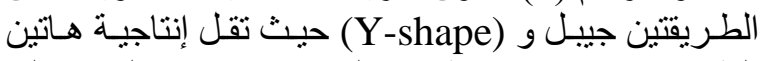
الطريقتين عن إنتاجية طريقة التكاعيب بنسبة تبلغ حوالى الى الى

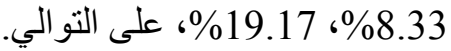

10. التقييم الإقتصادى للأسـاليب التكنولوجيـة المستخدمة فى إنتاج محصول العنب بعينة البحث لئن

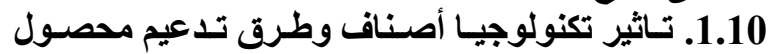

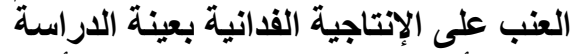

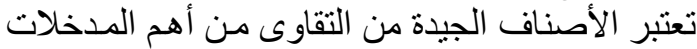

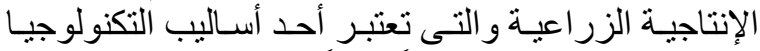

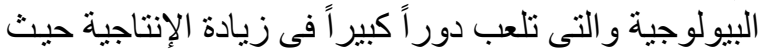

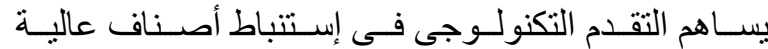
الإنتاجية، كما يعتبر الإختيار الأمتل لنظام التدعيم لأصناف التهاف

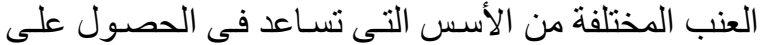
إنتاج مرتفع ذو صفات جودة عالية.

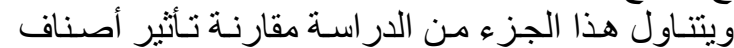

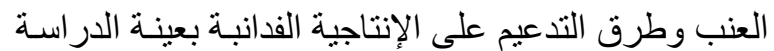

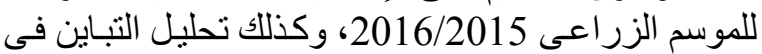

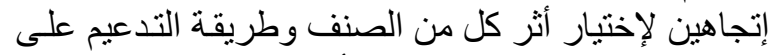

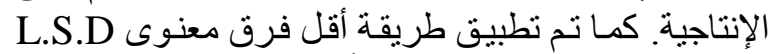

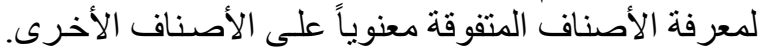

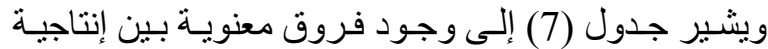
أصناف العنب موضول (7) التحليل.

جدول رقم (7): نتائج تحليل التباين لاختبار اثر كلاً من الصنف وطرق التدعيم على الإنتاجية القدانية لمحصول

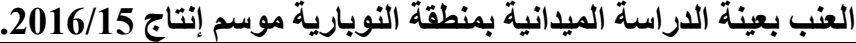

\begin{tabular}{|c|c|c|c|c|}
\hline ف & متوسط مجموع المربعات & مجموع مربعات & درجات الحرية & مصدر التباين \\
\hline$* * 153.54$ & 91.00 & 273 & 3 & أثر الصنف \\
\hline$* * 113.29$ & 64.00 & 128 & 2 & أثر طرق التدعيم \\
\hline \multirow[t]{3}{*}{1.89} & $\mathbf{1 . 3 3}$ & 6.8 & 6 & أثر الصنف وطرق التدعيم \\
\hline & 0.61 & 64.9 & 108 & الخطأ \\
\hline & & 464.22 & 119 & المجموع الكلى \\
\hline
\end{tabular}

حيث: (***) معنوية عند 0.01

المصدر: استمارة الاستبيان لعينة الدراسة للموسم الزراعي 2016/15 
جدول رقم (8): اختبار اقل فرق معنوى للفرق بين الإتتاجية الفدانية وفقاً لأصناف العنب بعينة الاراسة

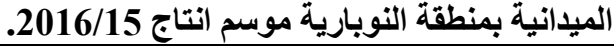

\begin{tabular}{|c|c|c|c|c|c|}
\hline سوبر يور & طومسون & فليم & كينج روبي & \multirow{2}{*}{\multicolumn{2}{|c|}{ المتوسنف }} \\
\hline 8.65 & 9.75 & 12 & 12.33 & & \\
\hline & & & صفز & 12.33 & كينج روبى \\
\hline & & صفز & 0.42 & 12 & فليم \\
\hline & صفر & 2.31 & 2.54 & 9.75 & طومسون \\
\hline صفر & 1.01 & 3.23 & 3.55 & 8.65 & سوبر يور \\
\hline
\end{tabular}

وبمقارنة تأثير إختلاف أصناف العنب وطرق التدعيم

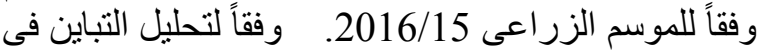

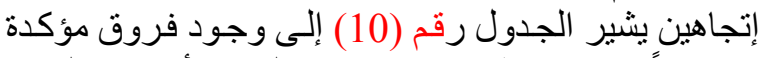

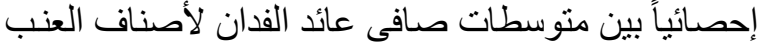

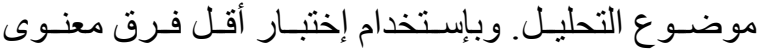

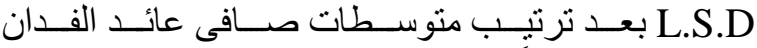

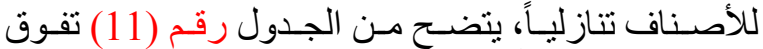

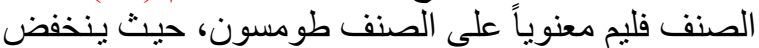

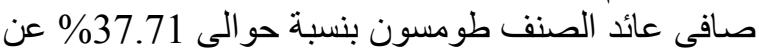

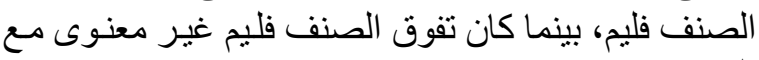

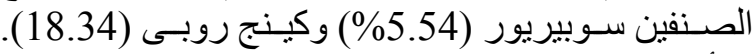
ويأتى الصنف سوبيريور في المرنبة الثنانيـة بعد الصنف

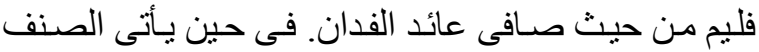

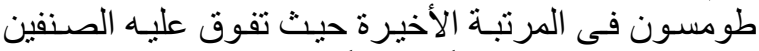

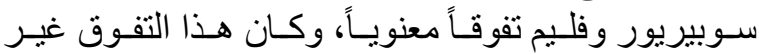
معنوى مع الصنف كينج روبى. كما ينضح من الجدول رقم (10) وجود فئر فروق مؤكدة

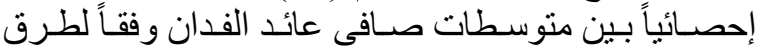

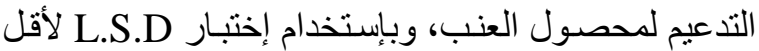

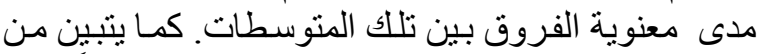

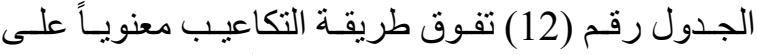

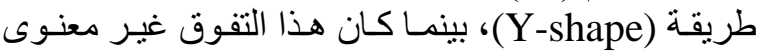

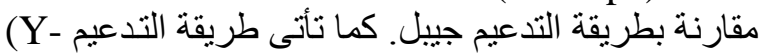

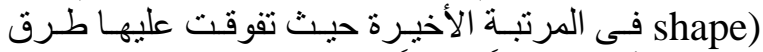

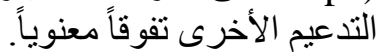
1.10. 3. تأثير تكنولوجيا أصناف وطرق تلائ تعيم محصول

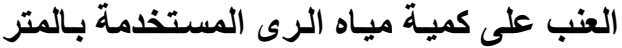

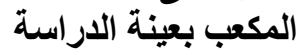

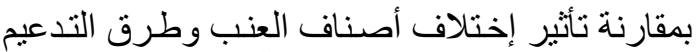

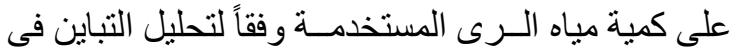

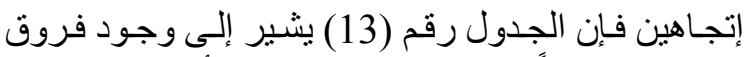

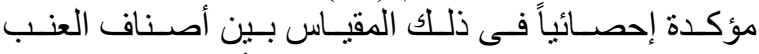

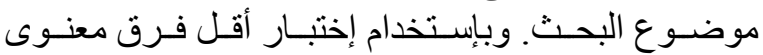

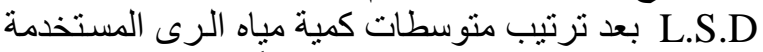

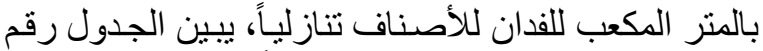

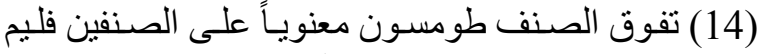

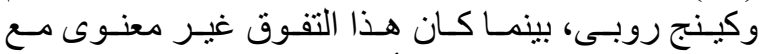

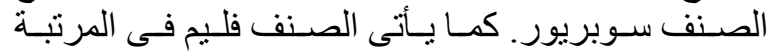

جدول رقم (9):اختبار اقل فرق معنوى للفرق بين الإنتاجية

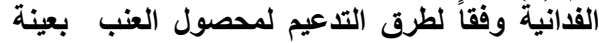

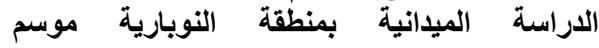
إنتاج2016/15

\begin{tabular}{|c|c|c|c|c|}
\hline Y-Shape & جبيل & التكاعيب & \multirow{2}{*}{\multicolumn{2}{|c|}{ طريقة التّعيم }} \\
\hline 9.7 & 11 & 12 & & \\
\hline & & صفر & 12 & التكاعيب \\
\hline & صفر & 1.35 & 11 & جبيل \\
\hline صفر & 1.49 & 2.68 & 9.7 & Y-Shape \\
\hline
\end{tabular}

حيث: (*) الى معنوية الفروق بين المتوسطين موضع المقارنة

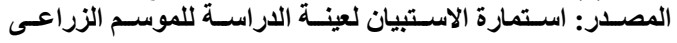
.2016/15

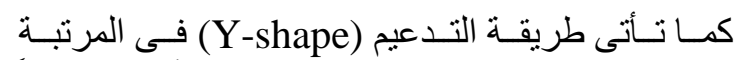

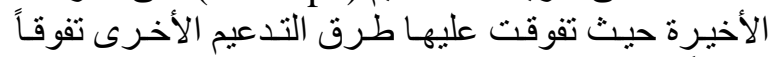

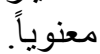

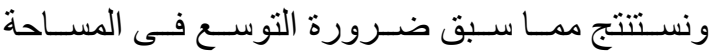

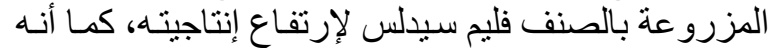
من الأصناف التصديرية المر غوبة في الأسو اق الخارجية التهية،

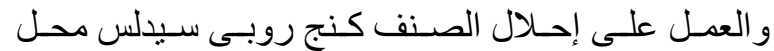

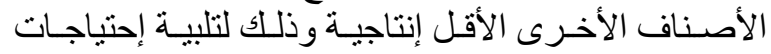

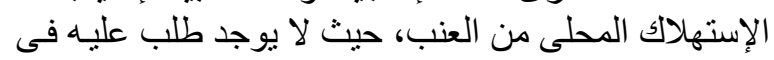

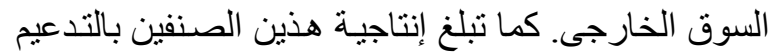

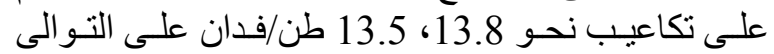

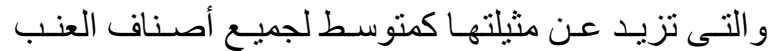

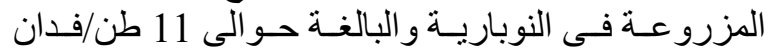

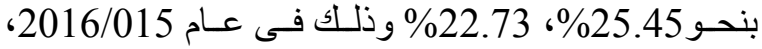

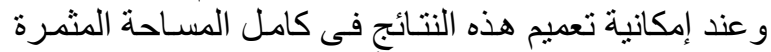

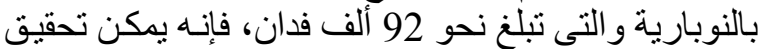

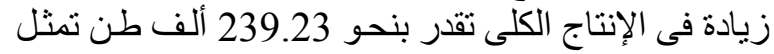

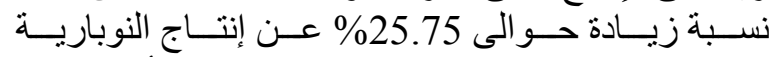

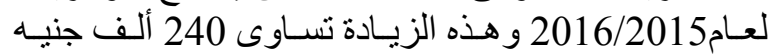

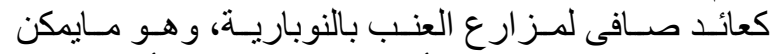

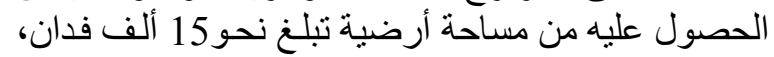

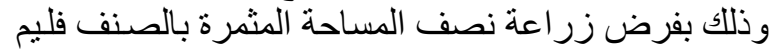

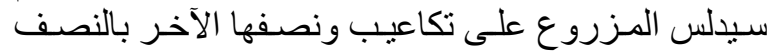
كنج روبى سيدلس المزروع على على تكاعيب.

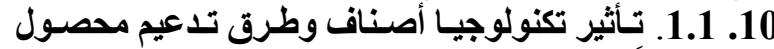
العنب وفقاً لمقياس صافى عائد الفان بعينة الدراسة 
جدول رقم (10): نتائج تحليل التباين لاختبار اثر كلاً من الصنف وطرق التدعيم على صافى العائد الفدانى لمحصول

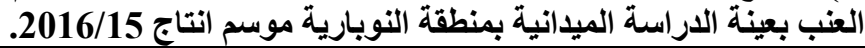

\begin{tabular}{|c|c|c|c|c|}
\hline$\dot{\theta}$ & متوسط مجموع المربعات & مجموع مربعات الانحرافات & درجات الحرية & مصدر التباين \\
\hline *** 6.74 & 90958774 & 272876323 & $\mathbf{3}$ & أثر الصنف \\
\hline${ }^{* * *} 9.3$ & 134478037 & 268956074 & 2 & أثر طرق التدعيم \\
\hline \multirow[t]{3}{*}{1.3} & 16012373 & 96074237 & 6 & أثُ الصنف وطرق التدعيم \\
\hline & 15874166 & 1714409877 & 108 & الغطأ \\
\hline & & 2244809392 & 119 & المجموع الكلى \\
\hline
\end{tabular}

حيث: (*) الى معنوية الفروق بين المتوسطين موضع المقارنة. المصدر: استمارة الاستبيان لعينة الاراسة للموسم الزئراعى 2016/15.

جدول رقم (11): إختبار أقل فرق معنوى للفرق بين متوسط صافى العائد للفدان وفقاً لأصناف العنب بعينة الاراسة الميدانية بمنطقة النوبارية موسم إنتاج

\begin{tabular}{|c|c|c|c|c|c|}
\hline طومسون & كينج روبى & سوير يور & فليم & & الصنف \\
\hline 6350 & 8325 & 9630 & 10195 & المتوسط & \\
\hline & & & صفر & 10195 & فليم \\
\hline & & صفر & 564.6 & 9630 & سوبر يور \\
\hline & صفز & 1306.4 & 1871.3 & 8325 & كينج روبى \\
\hline صفز & 1988.4 & 3293.2 & 3857.7 & 6350 & طومسون \\
\hline
\end{tabular}

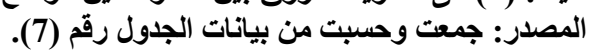

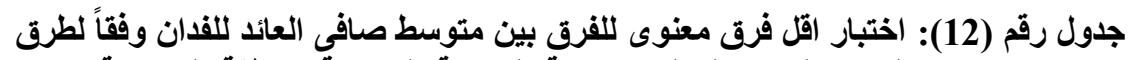

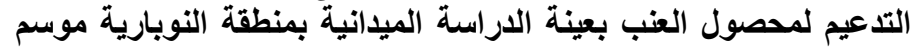

انتاج 2016/15.

\begin{tabular}{|c|c|c|c|c|}
\hline Y-Shape & جبيل & التكاعيب & \multirow[b]{2}{*}{ المتوسط } & طريقة التدعيم \\
\hline 6922 & 8830 & 10385 & & \\
\hline & & صفر & 10385 & التكاعيب \\
\hline & صفر & 1593 & 8830 & جبيل \\
\hline صفز & $* 2000$ & "3593 & 6925 & Y-Shape \\
\hline
\end{tabular}

المصدر: جمعت وحسبت من بيانات جدول (7).

المتوسطات يتبين مـن الجدول رقم (15) تفوق طريقة

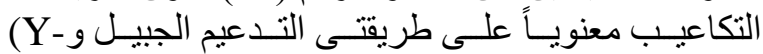
(Y-shape)

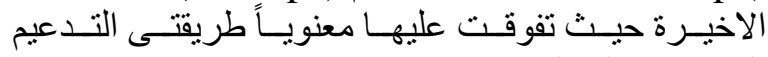

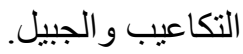

الأخيرة حيث تفوق عليه الصنفين طومسون وسوبريور

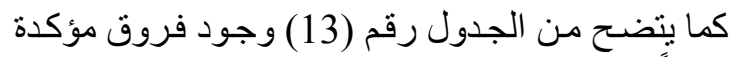

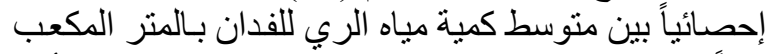

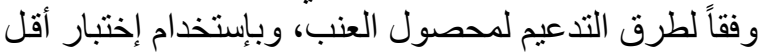
فرق معنوى L.S.D لاختبار مدى معنوية الفروق بين تلك الك

جدول رقم (13): نتائج تحليل التباين لاختبار اثر كلاً من الصنف وطرق التدعيم على كمية مياه الرى التدعيم لمحصول العنب بعينة

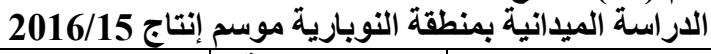

\begin{tabular}{|c|c|c|c|c|}
\hline$\dot{\theta}$ & متوسط مجموع المربعات & مجموع مربعات الانحرافات & لدرجات الحرية & مصدر التباين \\
\hline 9.34 & $\mathbf{3 8 2 5 5 9}$ & 1147678 & 3 & أثر الصنف \\
\hline 241.7 & 14884016 & 29768031 & 2 & أثر طرق التّعيم \\
\hline \multirow[t]{3}{*}{5.41} & 185790.43 & 1114743 & 6 & أثر الصنف وطرق التدعيم \\
\hline & 44145.16 & 4767677 & 108 & الخطأ \\
\hline & & 36788067 & 119 & المجمو ع الكلم \\
\hline
\end{tabular}

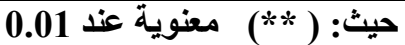

المصدر: استمارة الاستبيان لعينة الدراسة للموسم الزراعي $2016 / 15$ 
M. A. A. Abo El Naga and Z. E. Nassar.............................................................

جدول رقم (14): اختبر اقل فرق معنوي للفرق بين متوسط كمية مياه الري للفدان بالمتر المكب وفقاً لأصناف العبب بعينة

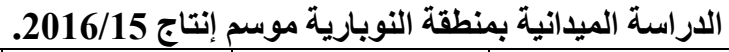

\begin{tabular}{|c|c|c|c|c|c|}
\hline فليم & كينج روبي & سوبر يور & طومسون & \multirow{2}{*}{\multicolumn{2}{|c|}{ المتوسط }} \\
\hline 6598 & 6642 & 6791 & 6830 & & \\
\hline & & & صفر & 6830 & طومسون \\
\hline & & صفز & 37.92 & 6791 & سوبر يور \\
\hline & صفر & 149.44 & 186.7 & 6642 & كينج روبي \\
\hline صفر & 45.22 & *192.61 & *232.2 & 6598 & فليم \\
\hline
\end{tabular}

حيث: (*) إلى معنوية الفروق بين المتوسطين موضع المقارنة. المصدر: جمعت وحسبت من بيانات الجدول رقم (10).

جدول رقم ( 15): اختبار اقل فرق معنوي للفرق بين متوسط كمية مياه الري للفدان بالمتر المكب وفقاً لطرق التدعيم لمحصول

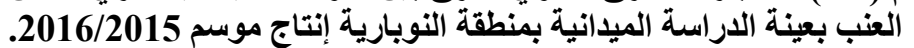

\begin{tabular}{|c|c|c|c|c|}
\hline Y-Shape & جبيل & التكاعيب & \multirow[b]{2}{*}{ المتوسط } & \multirow[t]{2}{*}{ طريقة التدعيم } \\
\hline & & & & \\
\hline & & صفر & 7350.21 & التكاعيب \\
\hline & صفر & 191.11 & 6659.82 & جبيل \\
\hline صفر & 531.21 & 1214.83 & 6135.41 & Y-Shape \\
\hline
\end{tabular}

حيث: (*) تثير إلى معنوية الفروق بين المتوسطين موضع المقارنة.

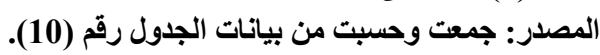

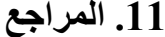

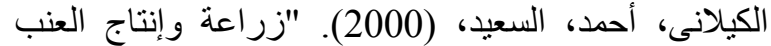

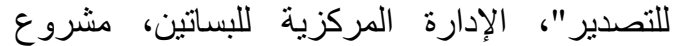

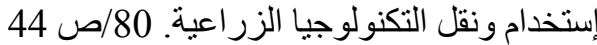

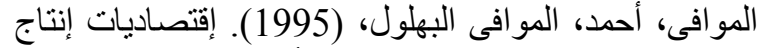

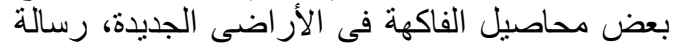

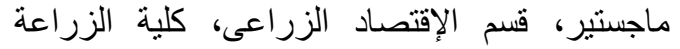

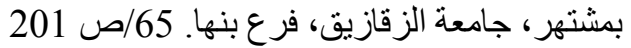

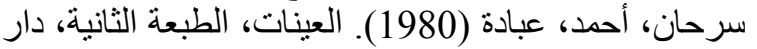
المعارف. 55/ص إد (166 166

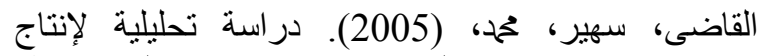

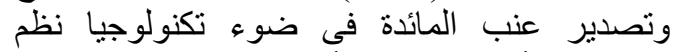

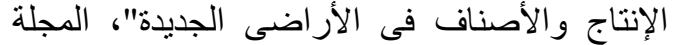

المصرية للإقتصاد الزر اعى المجلد الإندافي 15، العدد 2.

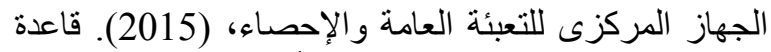
بيانات التجارة الخارجية. أعداد مختلفة. 2015 وزارة الزراعة وإستصلاح الأراضى، (2015). الإدارة

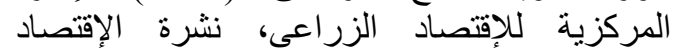
الزراعى، أعداد مختلفة (2000-2005). الزعادي،

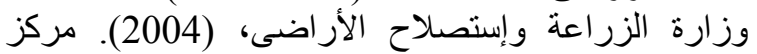

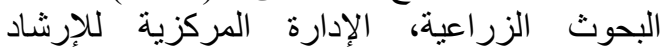
الزراعى، زراعة وإنتاج العنب، نشرة رقم الإداءة 849،

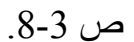

مركز المعلومات ودعم إتخاذ القرار، مجلس الوزراء

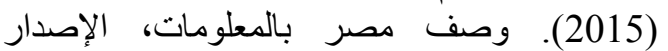

انتهى البحث ببعض التوصيات و التهى قد يؤدى تطبيقها

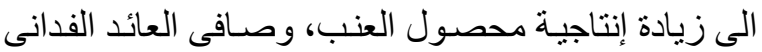

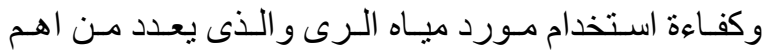

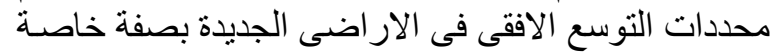
والانتاج الزر اعى المصرى بصفة الإنة عامة. التوصيات

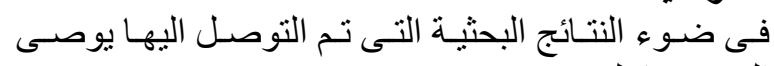

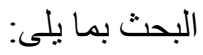

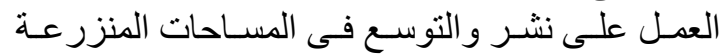

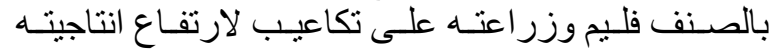

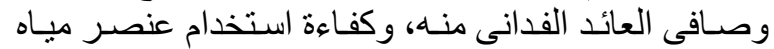

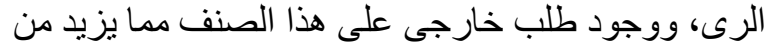

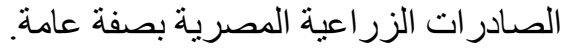

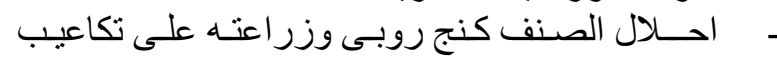

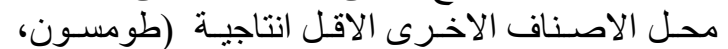

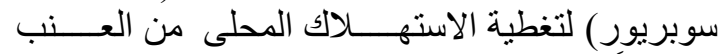

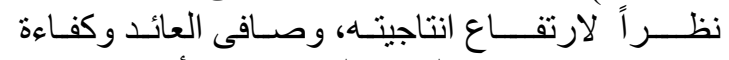
استخدام عنصر مياه الرى و التى تعد من أهم محددات التاني

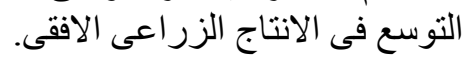

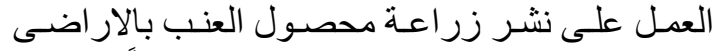

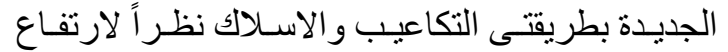

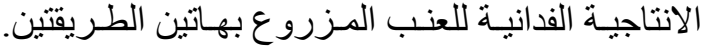

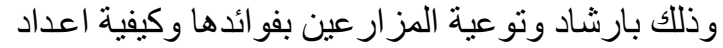

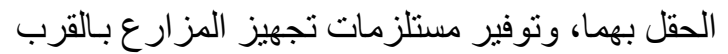

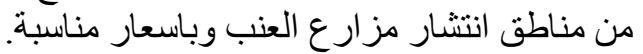

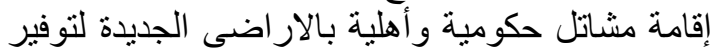

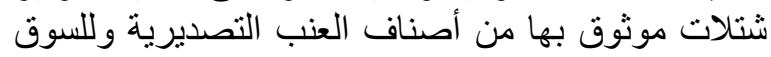
المحلى مرتفعة الانتاجية و المقاومة للامر اضن الن. 